\title{
Induction of cell migration and activation in mice by the freshwater sponge Drulia uruguayensis Bonetto \& Ezcurra de Drago, 1968 (Porifera: Metaniidae)
}

\begin{abstract}
Magalhães AO (1), Volkmer-Ribeiro C (2), Fujimoto LBM (3), Barbosa MF (3), Cardoso JL (4), Barcellos JFM (5), Silva CC (6), Campos RR (5), Cunha MCF (5), Freitas-Lemos AP (5), Dos-Santos MC (7)

(1) Federal University of Amazonas, Manaus, Amazonas State, Brazil; (2) Department of Invertebrate Zoology, Natural Sciences Museum, Zoo and Botanical Foundation of Rio Grande do Sul, Porto Alegre, Rio Grande do Sul State, Brazil; (3) Department of Pathology and Forensic Medicine, School of Medicine, Federal University of Amazonas, Manaus, Amazonas State, Brazil; (4) Vital Brazil Hospital, Butantan Institute, São Paulo, São Paulo State, Brazil; (5) Laboratory of Histology, Department of Morphology, Institute of Biological Sciences, Federal University of Amazonas, Manaus, Amazonas State, Brazil; (6) School of Chemical Engineering, State University of Amazonas, Manaus, Amazonas State, Brazil; (7) Laboratory of Immunology, Department of Parasitology, Institute of Biological Sciences, Federal University of Amazonas, Manaus, Amazonas State, Brazil.
\end{abstract}

\begin{abstract}
Freshwater sponges are abundant in the Amazon region and they have been known to cause dermatitis (acute inflammation) since the beginning of the $20^{\text {th }}$ century. To determine whether additional constituents, besides their body spicules, cause dermatological reactions in humans, an experimental study was developed and carried out using mice and Drulia uruguayensis prepared in three different forms: intact sponges (IS), macerated sponges (MS) or isolated spicules - megascleres (ISM). The cells most commonly involved in inflammatory reactions (mast cells, eosinophils and neutrophils), as well as intraepithelial lymphocytes and degranulated mast cells, were counted so that they could be used as parameters to determine which of the sponge preparations induced the greatest reaction. The effects of the sponge on the skin were then determined by histological analysis. The results obtained showed that IS caused the greatest inflammatory reaction $(p=0.000005)$, activating mainly mast cells $(p=0.0018)$. The histopathological analysis revealed a slight loss of continuity of the epidermis when ISM or IS were applied. These findings allow us to conclude that a structurally intact sponge can cause a greater inflammatory reaction in the first contact because of its ability to perforate the skin and allow inflammatory agents to enter. Other proteins present in dried sponge bodies could induce allergic but not toxic responses (in contact with the entire sponge, a large number of pharmacologically inert proteins may be introduced, with a potential allergen).
\end{abstract}

Key words: dermatitis, Amazonia, cauixi, freshwater sponges.

\section{INTRODUCTION}

Freshwater sponges are found from the north to the south of Brazil and are popularly known by such names as pó-de-mico d'água or coceira d'água and cauxi, cauixi or cauí, that vary depending on the region (1). In Amazonia, sponges are popularly known by the indigenous names cauixi, cauxi or cauí, which in the Tupi-Guarani language mean itch or burn (2).

Their spicules were extensively used by native tribes in Amazonia as temper in the manufacture of ceramic utensils to prevent the cracking of the material when it is fired (2-6). The use of spicules when making ceramics caused skin lesions, which were observed in Carajás indigenous women who worked as potters (4).

The first report of a skin lesion caused by sponges in Brazil may have been the description by Matta (7) of an accident involving a man who transported wood on the Solimões River. Six hours after coming into contact with a sponge, the man's fingers and palms had acquired an "intense red coloring, which became less intense towards the upper third of the anterior face of the forearms" (7).

In another incident in the municipality of Três Lagoas, Mato Grosso do Sul state, Brazil, 
municipal cleaning workers presented with swollen legs and allergic reactions. These were attributed to spongillite-containing sediment that had been deposited on the dried up bed of one of the three lakes from which the town takes its name. The spicules were later identified as belonging to two families of Porifera, Metaniidae and Spongillidae (8).

Accidents involving freshwater sponges from the genus Drulia Gray, 1867, that caused dermatitis have also been reported (9). Severe eye lesions were observed and described by Volkmer-Ribeiro et al. (10) and Volkmer-Ribeiro and Batista (11). Such lesions affected bathers diving with open eyes into the Araguaia River (Araguatins, Tocantins state, Brazil), who came into contact with tiny spicules that cover the gemmules of the species Drulia uruguayensis and Drulia ctenosclera. Those spicules were found during biopsy and surgically removed from the injured eyes (10).

However, it has not yet been established which part of the sponge causes skin lesions. In light of this fact, we designed and carried out experiments on mice using the sponge Drulia uruguayensis, which is abundant in Amazonian floodplain lakes, to determine the extent to which contact with the following three different forms of the sponge could induce a skin reaction: intact sponge, macerated sponge and isolated spicules (megascleres).

\section{MATERIALS AND METHODS}

\section{Sponges}

Specimens of the sponge Drulia uruguayensis, that were stuck to trunks and branches of a flooded forest, were collected from Praia de Aramanaí on the Tapajós River in the municipality of Belterra, Pará state, in January 2007 at the beginning of the rainy season. The chosen area is bounded by the coordinates $2^{\circ} 43^{\prime} 11^{\prime \prime} \mathrm{S} / 55^{\circ} 0^{\prime} 12^{\prime \prime} \mathrm{W}$ and $2^{\circ} 43^{\prime} 12^{\prime \prime}$ $\mathrm{S} / 55^{\circ} 0^{\prime} 13^{\prime \prime} \mathrm{W}$.

\section{Preparing the Sponges for the Experiments}

All the collected specimens were washed with water to remove any residues left from their environment (sand, flora and fauna). After being cleaned, the sponges were prepared and separated as follows: intact sponges, macerated sponges (using a pestle and porcelain mortar) and isolated megascleres kept at $-20^{\circ} \mathrm{C}$ until use.

\section{Obtaining the Isolated Spicules}

Spicules separated from the organic matrix were obtained according to the technique described by Volkmer-Ribeiro (12) with some modifications. Briefly, after being washed and dried, $136.1 \mathrm{~g}$ of the sponge was broken into fragments and placed in a 1-L vessel containing $250 \mathrm{~mL}$ of concentrated hydrochloric acid, analytical grade. This material was left immersed for one month so that all the organic matter in the sponge would dissolve. After being washed with distilled water to remove all the hydrochloric acid, the material was centrifuged and resuspended in a 3:1 ratio solution of diethyl ether and water.

After this process had been repeated several times and there was no material left in the ether/ water interface, distilled water was used to remove the residues and wash the spicules for the last time. This was done by repeating the following steps 25 times: addition of $12 \mathrm{~mL}$ of distilled water; vortexing at maximum speed until the pellet was completely resuspended; centrifugation at 3,500 rpm for 20 minutes; and removal of the supernatant with a pipette. The washed spicules were placed in an incubator twice at $80^{\circ} \mathrm{C}$ for three hours each time to dry. The dried spicules were then weighed to calculate the yield from the initial sponge sample. Ten-milligram aliquots of the spicules were then prepared and autoclaved.

\section{Chemical Analysis of the Purified Spicules}

The isolated spicules were analyzed by energy dispersive X-ray fluorescence (EDXRF). The tests were carried out in triplicate to determine the chemical composition of the spicules. The samples were analyzed in a Shimadzu EDX700 spectrometer (Japan), using $\mathrm{Rh}$ Ka radiation, a 10 mm collimator, vacuum atmosphere, 0 to $40 \mathrm{keV}$ scan and an exposure time of $200 \mathrm{~s}$.

\section{Animals}

Female adult non-isogenic mice from the Central Animal Colony at the National Amazonian Research Institute (INPA) weighing between 18 and $22 \mathrm{~g}(20 \pm 2 \mathrm{~g})$ were used in the experiments. The animals were separated randomly into a normal control group, a microporous adhesive tape control group and three test groups. Each group was housed in a separate plastic cage in a temperature-controlled environment and given feed and water ad libitum in the Pathology Laboratory at the School of 
Health Sciences, State University of Amazonas, Manaus. All procedures used in this study were approved by the Institutional Committee for the Care and Use of Laboratory Animals of the Federal University of Amazonas and met the International Guiding Principles for Biomedical Research Involving Animals (13).

\section{Preparing the Animals for the Experiments}

All the animals were partially shaved in the anterodorsal region with clean scissors immediately before the samples were applied.

\section{Testing the Skin Reaction to Intact Sponges, Macerated Sponges and Isolated Spicules (Megascleres)}

Based on the results of a previously performed kinetics test (data not shown) to determine the time intervals when cell activity peaked (2, 4 and 12 hours after application), the animals were separated into five test groups, namely:

- Group I - normal control: six mice that were only shaved.

- Group II - tape control: six mice, to which Cremer ${ }^{\circledast}$ hypoallergenic microporous adhesive tape was applied on the area that had been shaved.

- Group III - spicule group: 12 mice, which each received a $10 \mathrm{mg}$ application of isolated spicules.

- Group IV - intact sponge: 12 mice, which each received a $10 \mathrm{mg}$ application of intact sponge secured by tape.

- Group V - macerated sponge: 10 mice, which each received a $10 \mathrm{mg}$ application of macerated sponge secured by tape.

The spicules, macerated sponge and intact sponge were placed on the tape and kept in contact with the animals' shaved skin under manual pressure for one minute, after which the tape was removed and the animals returned to the cages. At the three time points (2, 4 and 12 hours after the applications), two animals from each control group and four from each experimental group were anesthetized, the skin corresponding to the area where the tape had been applied was removed and the animals were then sacrificed with diethyl ether. The removed skin fragments were placed in individual histology/biopsy cassettes (Erviegas, Brazil) and fixed in 10\% buffered formaldehyde.

\section{Histopathological Analysis}

In all the experiments, the skin fragments were placed in individual cassettes to be embedded in paraffin. Each paraffin block was then cut in a microtome (AO-820 Lupe ${ }^{\circledast}$, American Optical/O Patologista) to produce five slides and an average of eight microsections per slide. These were then stained with hematoxylin and eosin (two slides) and toluidine blue (one slide). In both experiments the cell count was carried out at random in an Olympus CX40 optical microscope (Japan). For each microsection, ten fields were read at a magnification of 400x. The following cell types were counted: total mast cells (intact and degranulated) and degranulated mast cells on slides stained with toluidine blue; and neutrophils, intraepithelial lymphocytes and eosinophils on slides stained with hematoxylin and eosin.

\section{Statistical Analysis}

Correlations between the applications and the variations in cell counts were determined by factorial ANOVA using Statistica ${ }^{\varpi}$ version 7.0 (StatSoft, EUA).

\section{RESULTS}

\section{Yield and Chemical Analysis of Purified Spicules}

After the separation process, the final yield of the isolated spicules was $83.98 \mathrm{~g}$, equivalent to $61.7 \%$ of the total weight of the intact sponge (136.1 g) (Figure 1). The spicules obtained in this manner were loose isolated megascleres (from around 145 to 818 micrometers long) free of any environmental contamination. Spicules from the gemmules (gemmoscleres) and microscleres attached to the pinacoderm of the sponges were not detected when the spicules were being checked for impurities. Because these are smaller and lighter, most were lost during the various centrifugation and resuspension steps.

Chemical analysis of the spicules (megascleres) identified the following components: silica, $18.862 \%(\mathrm{w} / \mathrm{w})$; calcium, $0.098 \%(\mathrm{w} / \mathrm{w})$; iron, $0.002 \%(\mathrm{w} / \mathrm{w})$; copper, $0.011 \%(\mathrm{w} / \mathrm{w})$; zinc, $0.002 \%$ $(\mathrm{w} / \mathrm{w})$. The remaining mass, $81.025 \%(\mathrm{w} / \mathrm{w})$, is related to the chemical elements hydrogen and oxygen, present in the structure of the molecules that form the spicules. 


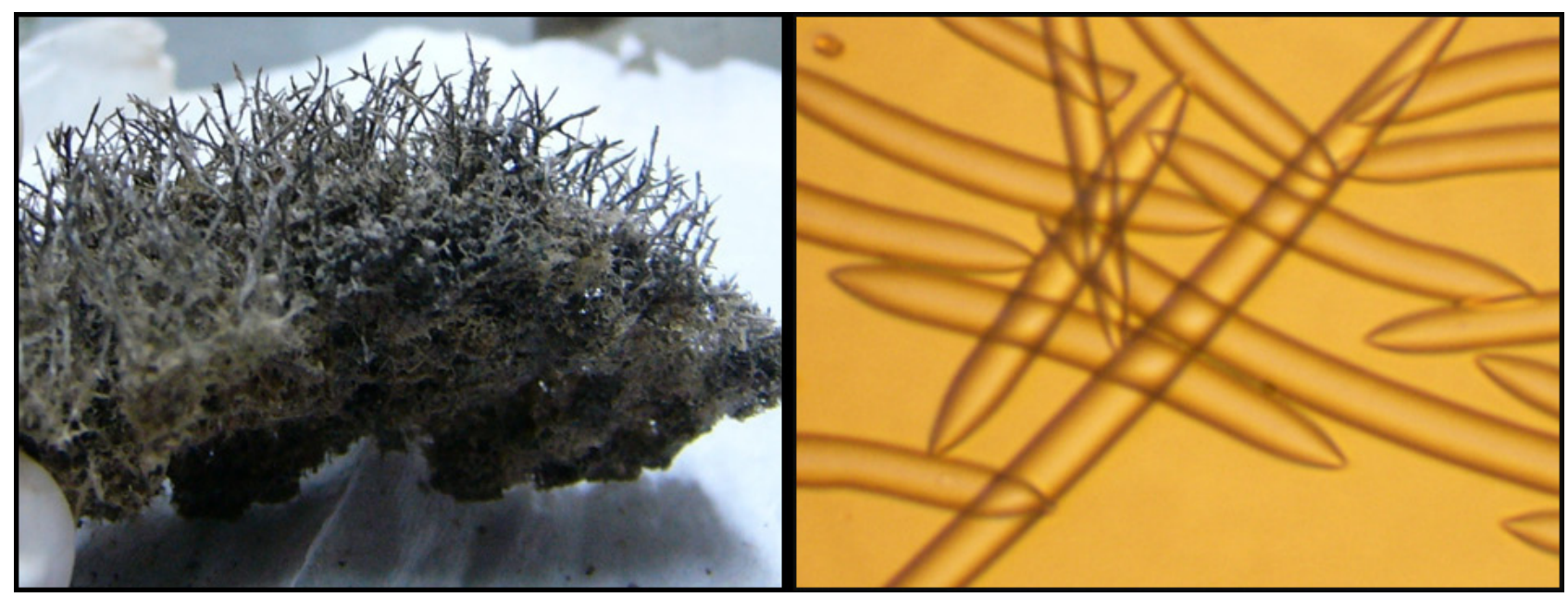

Figure 1. The freshwater sponge Drulia uruguayensis, showing its tree-like morphology, and some of its isolated spicules.

\section{Cellular Response Induced by the Macerated} Forms, Intact Forms and Isolated Spicules

Analysis by factorial ANOVA of the cell counts used as parameters to determine which part of the sponge causes skin lesions revealed that the intact sponge produced the most statistically significant results. The results for the cleaned and autoclaved isolated spicules (megascleres) were the least statistically significant and were slightly lower than those for the macerated sponge (Figure 2).

\section{Histopathological Appearance}

The following features were observed during the histopathological analysis (Figure 3).

After two hours: the only abnormal feature in the tape control group was a thickening of the epidermis. In mice treated with the different sponge forms, the following abnormal features were observed: inflammatory infiltrate containing neutrophils, eosinophils, lymphocytes and histocytes and abundant mast cells (very few of which were degranulated) in the dermis, and slightly dilated and congested capillaries in the hypodermis.

After four hours: the thickening of the epidermis observed at the 2-hour time point in the tape control group was no longer visible. However, in the mice that were given applications of isolated spicules (megascleres) or intact sponge, there were gaps in the keratinocyte layer, the gap being smaller for the intact sponge. The group that received isolated megascleres presented keratinocytes with condensed hyperchromatic nuclei along the edge. The macerated sponge caused a thinning of the epidermis and showed a layer of keratinocytes with condensed, hyperchromatic nuclei. Apart from the normal control group, which had only a small amount of diffuse infiltrate, all the other groups had inflammatory infiltrate in the dermis. Greater amounts of this infiltrate were observed in the dermis of mice that had been given applications containing intact sponge. Hyalinized collagen fibers were observed in all the groups except the normal control group and were thickest in group $\mathrm{V}$. Isolated spicules (megascleres) produced amorphous hyaline material below the incomplete keratinocyte layer. The capillaries in the hypodermis were slightly dilated and congested.

After twelve hours: for all the applications, including the controls, there were no abnormal features in the epidermis, which consisted of two or three layers. The dermis presented a small amount of diffuse infiltrate, and the capillaries were slightly dilated and congested.

\section{DISCUSSION}

In the specific case of Amazonian freshwater sponges, the existing reports $(3,5,7)$ state that handling sponges causes dermatitis but do not suggest a possible pathogenic agent.

Our results show that application of intact sponges induced a greater inflammatory reaction $(\mathrm{p}=0.000005)$ than macerated sponges or isolated spicules (megascleres) (Figure 1). Matta (7) and Isbister and Hooper (14) described cases in which direct contact with intact sponges caused acute dermatitis. In both cases the incidents occurred 


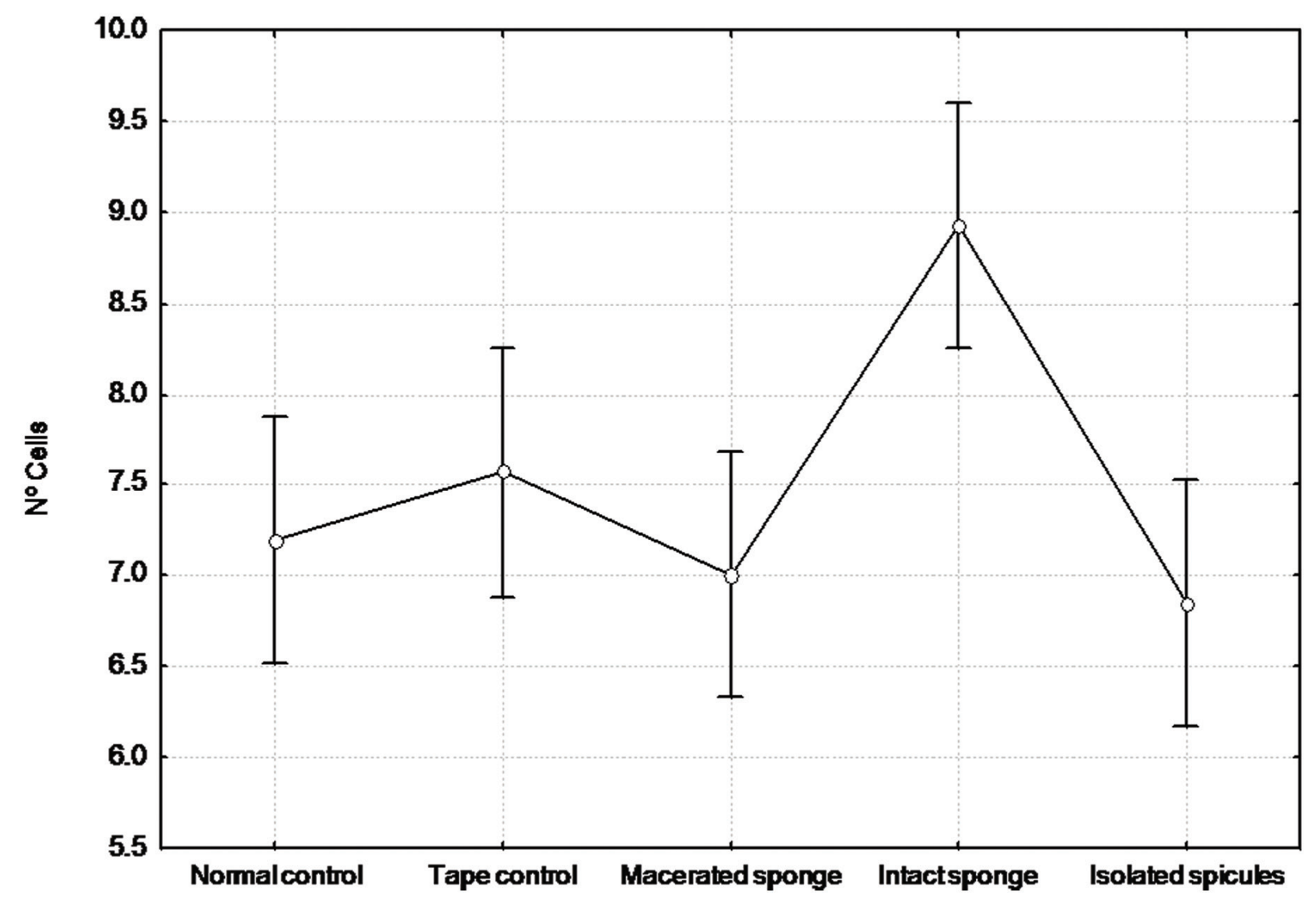

Figure 2. Graph showing the relationship between the different sponge forms and the cell-number variation, with $\mathrm{p}<0.05$.

in the water, suggesting that the sponges were alive. In this state, Porifera, particularly marine Porifera, produces substances such as alkaloids and purines that have proven biological action (15-19). We used dried, dead sponges, thus maintaining the possibility that a biological agent may have influenced our results to a minimum, although to the best of our knowledge there are no studies showing the effects of chemicals released by freshwater Amazonian Porifera in the literature.

The greater capacity of the intact form of the sponge to cause an inflammatory reaction may be a result of the morphology of the species Drulia uruguayensis. Its tree-like structure, with bunches of spicules (megascleres), forms pointed external branches, allowing the intact sponge to cause a deeper point-like lesion in the epidermis than the other sponge forms, while at the same time preventing the sponge as a whole from touching the skin (20). These characteristics suggest that the mast cells may have been activated by the direct mechanical action of the spicules as they perforated the epidermis and reached the connective tissue $(21,22)$. Within the bunches of spicules there may also have been unknown chemical substances from the sponges themselves or from the water environment that, together with the physical aggression, induced a mast cell reaction with significant degranulation $(\mathrm{p}=$ 0.000310).

By testing the ability of isolated megascleres to induce inflammation, we have shown, at a minimum, that the category of spicules is not involved in the inflammatory reaction and that they merely facilitate entry for other aggressive agents. Burke (23), Rosson and Tolle (24) and Thomas and Scott (25) suggested that the wound caused by spicules allows toxins from the sponge to enter the skin, leading to the inflammatory reaction observed.

Another possibility is that the spicules that cause the lesions were gemmoscleres or microscleres given that a small quantity of either or both could have been present in the aliquots used in the experiments (although these were not found in the samples that were analyzed to check for impurities). This would confirm the 


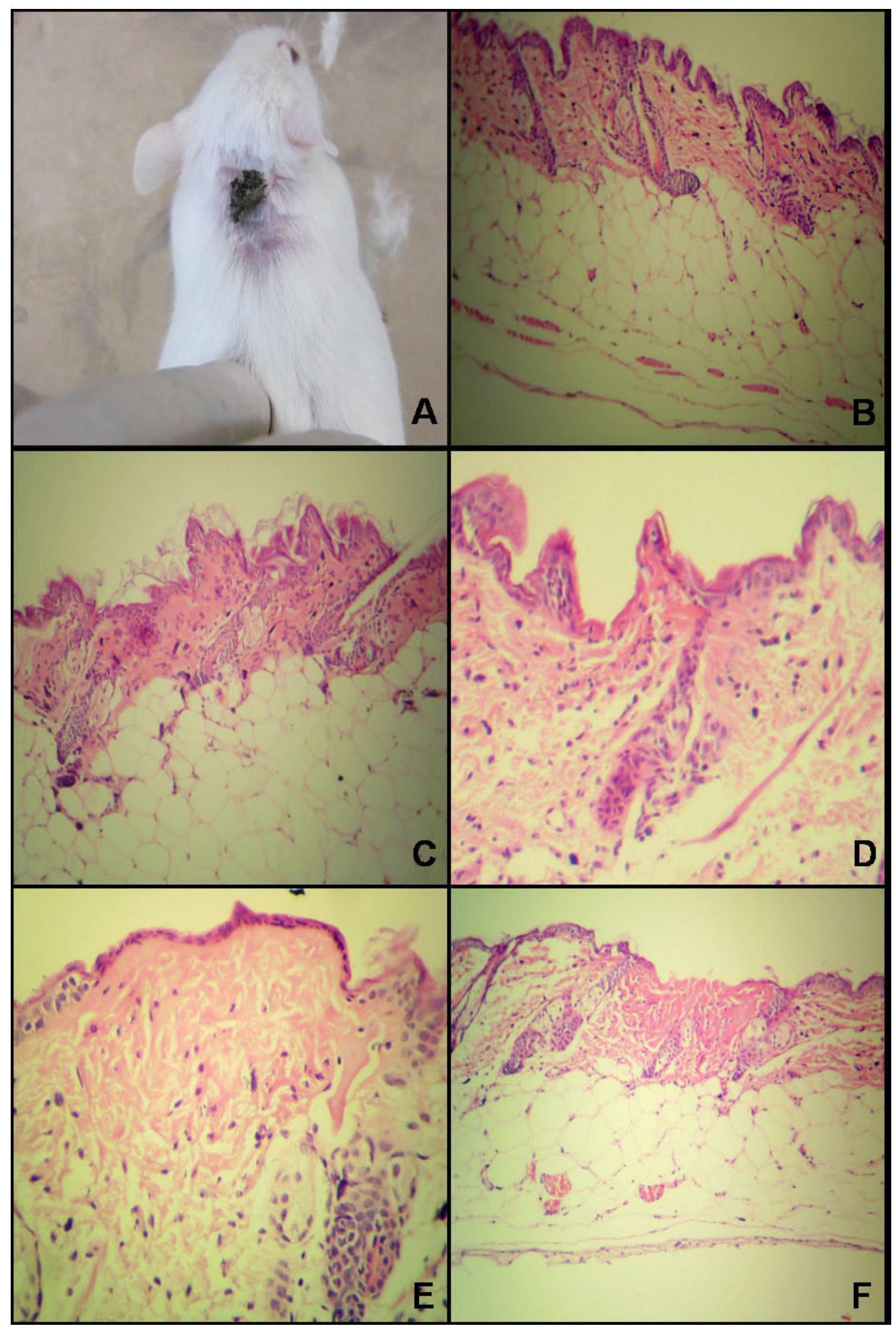

Figure 3. Histopathological lesions: (A) application site in mice, histological appearance of the animals after four hours; (B) negative control, the general architecture of the skin, particularly the epidermis, is preserved; (C) tape control, animals that received an application of: (D) intact sponges, (E) macerated sponges, and (F) isolated spicules. 
ability of this type of spicule to cause lesions, as observed by Volkmer-Ribeiro et al. (10) in eye lesions in Araguatins, Tocantins state, Brazil.

Nevertheless, observation of the histopathological lesions in mice that received an application of spicules showed that the lesion was the most severe after four hours, when gaps in the epidermis were larger than those caused by the intact sponge although the induction of cells by the spicules was found to be less intense, a finding that can be explained by the characteristics of the spicules and the application. Because the spicules are very light, more of them were required to constitute the $10 \mathrm{mg}$ used in the experiment than were present in the applications of macerated or intact sponge. In addition, as both ends of the megascleres are implicated, one minute of friction may be sufficient to cause loss of the animal's epidermal layer (20). Our results thus allow us to conclude that the intact form of the sponge caused the greatest inflammatory reaction and was followed by the macerated form, which has a limited capacity to induce this type of reaction, probably because it does not possess the bundles of spicules that penetrate the epidermis and connective tissue; and that purified and autoclaved isolated megascleres do not cause a skin reaction by themselves but can cause mechanical injuries that allow the entry of other agents that can induce an inflammatory reaction.

As this study did not investigate other components of the intact sponge - such as gemmoscleres, microscleres and chemical and microbiological compounds, which represent $38.3 \%$ of its total weight - further studies are required to establish the involvement of these components in lesions caused by the intact sponge.

\section{COPYRIGHT}

(C) CEVAP 2011

\section{SUBMISSION STATUS}

Received: August 31, 2010.

Accepted: December 6, 2010.

Abstract published online: December 7, 2010.

Full paper published online: February 28, 2011.

\section{CONFLICTS OF INTEREST}

There is no conflict.

\section{FINANCIAL SOURCE}

The State of Amazonas Research Foundation (FAPEAM), Manaus, Amazonas State, Brazil, provided the financial grants.

\section{ETHICS COMMITTEE APPROVAL}

The present study was approved by the Institutional Committee for the Care and Use of Laboratory Animals of the Federal University of Amazonas and met the International Guiding Principles for Biomedical Research Involving Animals (CIOMS, 1985).

\section{CORRESPONDENCE TO}

MARIA CRISTINA DOS SANTOS, Laboratório de Imunologia, Departamento de Parasitologia, Instituto de Ciências Biológicas, Universidade Federal do Amazonas, Av. General Rodrigo Octávio Jordão Ramos, 3000, Campus Universitário, Coroado I, Manaus, AM, Brasil. Phone: + 55929981 3473. Email: mcsantos@ ufam.edu.br.

\section{REFERENCES}

1. Volkmer-Ribeiro C. Esponjas. In: Jolly CA, Bicudo CEM. Biodiversidade do Estado de São Paulo, síntese do conhecimento ao final do século XX. 4: Invertebrados de água doce. São Paulo: FAPESP; 1999. p. 1-9.

2. Matta AD. Cai e cauxí. Rev Inst Geog Hist do Amazonas. 1934;4(4):129-32.

3. Brazil TPS. Cauicy. Rio de Janeiro: Leuzinger; 1938. p. 11-23.

4. Machado OXB. Zoologia: espongiários (Porifera). Imprensa Nacional: Rio de Janeiro; 1947. Publication 102, appendix 5, 4 p.

5. Hilbert PPA. Cerâmica arqueológica da região de Oriximiná. Belém: Instituto de Antropologia e Etnologia do Pará; 1955. V. 9, p. 33-337.

6. Gomes DMC. Cerâmica arqueológica da Amazônia: vasilhas da coleção tapajônica MAEUSP. São Paulo: Editora da Universidade de São Paulo/Fapesp/Imprensa Oficial do Estado; 2002.

7. Matta AD. Epidermatite erythematosa devida a espongiário de água doce. Brasil - Médico. 1932;19:435-6.

8. Lorenz-Silva JL. O espongilito de Três Lagoas, MS: registro e caracterização com ênfase em micropaleontologia. São Leopoldo: Universidade do Vale do Rio dos Sinos; 2004.

9. Magalhães AO, Volkmer-Ribeiro C, Barcellos JFM, Cardoso JLC, Dos-Santos MC. Report on two cases of human skin injuries caused by 
sponge spicules at Amazon. In: International Sponge Symposim, 7th ed. Rio de Janeiro: Museu Nacional; 2006. p. 150.

10. Volkmer-Ribeiro C, Lenzi HL, Oréfice F, PelajoMachado M, Alencar LM, Fonseca CF, et al. Freshwater sponge spicules: a new agent of ocular pathology. Mem Inst Oswaldo Cruz. 2006;101(8):899-903

11. Volkmer-Ribeiro C, Batista TCA. Levantamento de cauxi (Porífera, Demospongiae), provável agente etiológico de doença ocular em humanos, Araguatins, rio Araguaia, Estado do Tocantins, Brasil. Rev Bras Zool. 2007;24(1):133-43.

12. Volkmer-Ribeiro C; Rutzler K. Pachyrotula, a new genus of freshwater sponges from New Caledonia (Porifera: Spongillidae). Proc Biol Soc Wash. 1997;110(4):489-501.

13. Council for International Organizations of Medical Sciences (CIOMS). World Health Organization. Geneva (Switzerland); c19492010 [update 2010 March 15, cited 2010 March 16]. Available from: http://www.cioms.ch/ publications/guidelines/frame_guidelines.htm

14. Isbister GK, Hooper JNA. Clinical effects of stings by sponges of the genus Tedania and a review of sponge stings worldwide. Toxicon. 2005;46(7):782-5.

15. Berlinck RGS, Ogawa CA, Almeida AMP, Sanchez MAA, Malpezzi ELA, Costa LV, et al. Chemical and pharmacological characterization of halitoxin from Amphimedon viridis (Porifera) from the southeastern Brazilian coast. Comp Biochem Physiol. 1996;115(2):155-63.

16. Chehade CC, Dias RLA, Berlinck RGSC, Ferreira AG, Costa LV, Rangel $M$, et al. 1,3-Dimethylisoguanine, a new purine from the marine sponge Amphimedon viridis. J Nat Prod. 1997;60(7):729-31.
17. Muricy G, Hajdu E, Araujo FV, Hagler A. Antimicrobial activity of Southwestern Atlantic shallow-water marine sponges (Porifera). Sci Mar. 1993;57(4):427-32.

18. Torres YR, Berlinck RGS, Magalhães A, Schefer AB, Ferreira AG, Hajdu E, et al. Arenosclerins $\mathrm{A}-\mathrm{C}$ and haliclonacyclamine $\mathrm{E}$, new tetracyclic alkaloids from a Brazilian endemic Haplosclerid sponge Arenosclera brasiliensis. J Nat Prod. 2000; 63(8):1098-105.

19. Torres YR, Berlinck RGS, Nascimento GGF, Fortier SC, Pessoa C, Moraes MO. Antibacterial activity against resistant bacteria and cytotoxicity of four alkaloid toxins isolated from the marine sponge Arenosclera brasilienses. Toxicon.2002;40(7):885-91.

20. Volkmer-Ribeiro C, Tavares MCM. Redescrição de Drulia uruguayensis Bonetto \& Ezcurra de Drago, 1968 com redefinição do gênero Drulia Gray, 1867 (Porifera: Metaniidae). Biociências. 1995;3(1):183-205.

21. Galli SJ, Tsai M. Mast cell: versatile regulators of inflammation, tissue remodeling, host defense and homeostasis. J Dermatol Sci. 2008;49(1):719.

22. Metz M, Maurer M. Mast cells: key effector cells in immune responses. Trends Immunol. 2007;28(5):234-41.

23. Burke WA. Cutaneous reactions to marine sponges and bryozoans. Dermatol Ther. 2002;15(1):26-9.

24. Rosson CL, Tolle SW. Management of marine stings and scrapes. West J Med. 1989;150(1):97100 .

25. Thomas C, Scott S. All stings considered: first aid and medical treatment of Hawaii's marine injuries. Honolulu: University of Hawaii Press; 1997. p. 86-9. 